\title{
Prognostic Value of Red Cell Distribution Width in Critically III Patients and Comparison with Intensive Care Unit Scoring Systems
}

\author{
Emin Fatih Vişneci ${ }^{1}$, Başar Cander ${ }^{2}$, Mehmet Gül², Zerrin Defne Dündar², Ali Dur², Abdullah Sadık Girişgin² \\ ${ }^{1}$ Clinic of Emergency Medicine, Konya Training and Resarch Hospital, Konya, Turkey \\ ${ }^{2}$ Department of Emergency Medicine, Necmettin Erbakan University Meram School of Medicine, Konya, Turkey
}

\begin{abstract}
Aim: This study aimed to investigate the prognostic value of lactate and red cell distribution width (RDW) parameters of patients admitted to emergency service and critical care unit (CCU).

Materials and Methods: A total of 147 patients hospitalized in the CCU of Necmettin Erbakan University, Meram Faculty of Medicine, Department of Emergency Medicine, were included in the study. Vital signs, laboratory results, lactate, and RDW values of the patients were recorded. Acute Physiology and Chronic Health Evaluation II (APACHE II) and sequential organ failure assessment (SOFA) scores were calculated. Duration of hospitalization and intensive care unit stay and mortalities were recorded. Chi-square, Fisher's exact chi-square, and Student t tests were used for statistical analyzes, and Mann-Whitney $\mathrm{U}$ test was used for comparing nonparametric data that were not compatible with a normal distribution. $\mathrm{P}<0.05$ were accepted as statistically significant. Spearman correlation analysis was used to assess whether a linear correlation existed between the parameters.

Results: A statistically significant correlation was found between the duration of stay in the CCU for $<7$ days and total duration of hospitalization ( $p<0.001$ ). Also, statistically significant correlations were observed between mortalities of 28 days and 3 months, APACHE II and SOFA scores, and mean lactate (for 24 $h$ and during hospitalization) and RDW values ( $<<0.001, p<0.001, p<0.001$, and $p<0.05$, respectively). Moreover, correlations were noted between APACHE II scores, lactate value during the first admission, and SOFA scores $(p<0.001)$. Correlations were also observed between $48-h$ SOFA scores and RDW and lactate values $(p<0.001)$.
\end{abstract}

Conclusion: SOFA and APACHE II are the scoring systems used in practice. Efficiencies for mortality assessment of critical patients were confirmed. This study showed that lactate and RDW values, which were compatible with the scoring systems, could be used for assessing prognosis. Wider and more comprehensive studies that can assess scoring systems and lactate and RDW values together for prognostic identification are required to validate the findings.

Keywords: Acute physiology and chronic health evaluation II score, critical patient, intensive care, lactate, red cell distribution width, sequential organ failure assessment score

\section{Introduction}

Emergency services and emergency critical care units (CCUs) are the most frequently visited departments for the diagnosis and follow-up of critically ill patients (1). CCUs are the optional units among emergency services in Turkey where intensive care patients are followed up. The CCU of Necmettin Erbakan University, Meram School of Medicine, Department of Emergency Medicine, is also a tertiary intensive care unit (ICU). Longer durations for the diagnosis and transfer of critical patients to the other clinics increase the importance of emer- gency CCUs. Remarkable knowledge of critical patient follow-ups and close follow-up of prognostic signs are necessary. Blood lactate level is one of the most frequently used parameters (2). Tissue hypoxia during shock and the condition after shock resuscitation are the indicators of prognosis for critical cases in terms of identification of severity and mortality risk of diseases and must be considered a useful indicator for conditions such as etiologic diagnosis $(3,4)$. Red cell distribution width (RDW) is one such indicator. RDW is an index for the variability of erythrocyte volumes and can be used for detecting the anisositosis grade. The RDW value is known to increase in many types of anemia,

This study was presented at the $1^{\text {st }}$ International Critical Care and Emergency Medicine Congress, 06-08 November 2013, istanbul, Turkey.

Correspondence to: Emin Fatih Vişneci e-mail: drfatihvisneci@hotmail.com

Received: 03.01.2017 - Accepted: 06.02.2017

(c) Copyright 2017 by Emergency Physicians Association of Turkey - Available online at www.eajem.com

DOI: 10.5152/eajem.2017.43531 
hemoglobinopathies, and conditions such as blood transfusion. Recent studies have shown that RDW increases in cardiopulmonary diseases, such as coronary artery disease, heart failure, and pulmonary hypertension, and is strongly correlated with the prognosis $(5,6)$.

Acute Physiology and Chronic Health Evaluation II (APACHE II) and sequential organ failure assessment (SOFA) are highly efficient scoring systems for assessing disease severity and mortality of patients in ICUs.

The aim of this study was to detect the prognostic value of RDW and lactate for the patients admitted to emergency services and those in CCUs and to compare them with regard to scoring systems.

\section{Materials and Methods}

This was a prospective and observational study conducted in the CCU of Necmettin Erbakan University, Meram School of Medicine, Department of Emergency Medicine. Ethical approval was obtained. Male and female patients aged $>18$ years who provided informed consent and filled the study form completely were included in the study. Exclusion criteria were as follows: patients who received erythrocyte suspension during their stay in the CCU and in the last 2 weeks, cases with known hematologic malignancy, patients diagnosed with myelodysplastic syndrome, pregnant patients, and patients with malignancies and bone marrow invasion. A total of 647 patients were hospitalized in the CCU during the study period, and 164 of these, whose examinations were completed and who met the inclusion criteria, were included in the study. Three patients were excluded on their or relatives' request; eight patients due to their transfer to another center and six patients based on their blood transfusion needs were excluded from the study. Thus, 147 patients were included in the study. Demographic data, vital signs, and laboratory examinations of the patients were recorded starting from their stay in the CCU. The mean lactate values at the first admission, during the first $24 \mathrm{~h}$, at $48 \mathrm{~h}$, and during the CCU stay were recorded. In addition, the mean RDW value at the first admission, at $48 \mathrm{~h}$, and during the follow-up in the CCU was recorded. Moreover, APACHE II and SOFA scores at first admission and $48 \mathrm{~h}$ were calculated. Total hospitalization durations were identified for the patients who stayed in the CCU for $<7$ days and $>7$ days. Mortalities at 28 days and 3 months were recorded.

\section{Statistical analysis}

The data were statistically assessed using Statistical Package for Social Sciences version 22.0 (IBM Corp.; Armonk, NY, USA). The chisquare test and when necessary Fisher's exact chi-square test were used for categorical data. The Student $t$ test was used for parametric data, and the Mann-Whitney $U$ test was used for comparing nonparametric data that were not compatible with a normal distribution. $\mathrm{p}<0.05$ was accepted as statistically significant. The Spearman correlation analysis was used to assess whether a linear correlation existed between some parameters and if the correlation coefficient ( $r$ ) was 0.00-0.25 accepted as extremely weak, 0.26-0.49 accepted as weak, 0.50-0.69 accepted as moderate, 0.70-0.89 accepted as high, and 0.90-1.00 accepted as extremely high.

\section{Results}

The mortality and discharge rates of 147 patients included in the study according to their gender are shown in Table $1 ; 78$ patients (53.1\%) were males and 69 (46.9\%) were females. The mean \pm stard
Table 1. In-hospital mortality and discharge rates according to patient gender

\begin{tabular}{|l|c|c|c|}
\hline & Death, $\mathbf{n}(\%)$ & Discharge, $\mathbf{n}(\%)$ & Total, $\mathbf{n}(\%)$ \\
\hline Male & $34(57.6)$ & $44(50)$ & $78(53.1)$ \\
\hline Female & $25(42.4)$ & $44(50)$ & $69(46.9)$ \\
\hline Total & $59(100)$ & $88(100)$ & $147(100)$ \\
\hline
\end{tabular}

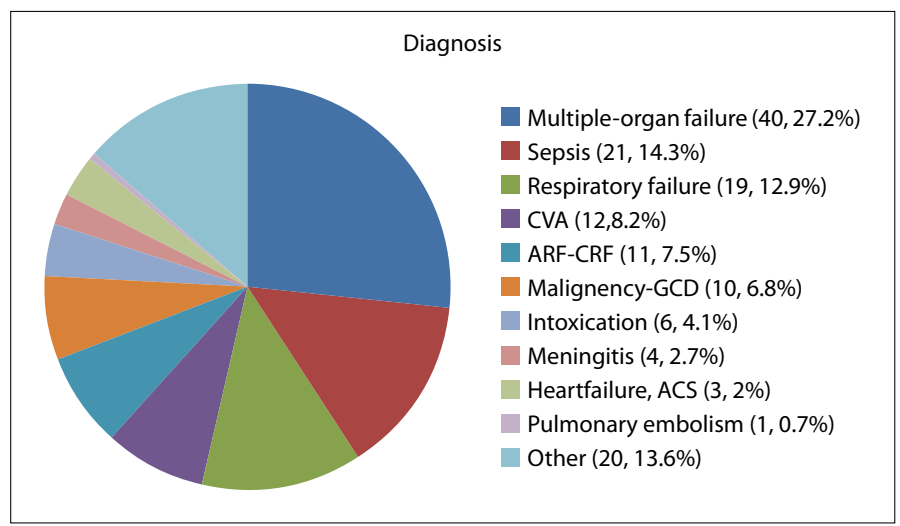

Figure 1. Distribution of patients according to diagnosis

CVA: cerebro vascular accident; ARF: acute renal failure; CRF: chronic renal failure; GCD: general condition disorder

deviation age was $67 \pm 15$ years; 59 patients $(40.1 \%)$ died in the hospital, and 88 (59.9\%) were discharged.

The distribution of the patients according to their diagnoses is shown in Figure 1. The most frequent diagnoses were sepsis and multiple organ failure.

The mean APACHE II score at the first hospitalization in the CCU was $16 \pm 6.5$. The SOFA score at first hospitalization and at $48 \mathrm{~h}$ was $5.6 \pm 2.8$ and $5.9 \pm 2.9$, respectively. The mean RDW value at the first hospitalization, at $48 \mathrm{~h}$, and during their stay in the CCU was $13.8 \pm 2.5$, $13.8 \pm 2.6$, and $13.8 \pm 2.5$, respectively. The mean lactate value at first admission in the CCU, at $24 \mathrm{~h}$, mean value at 24 and $48 \mathrm{~h}$ was $2.6 \pm 2.5$, $1.9 \pm 1.6,2.2 \pm 1.7$, and $1.7 \pm 1.3$, respectively. The mean lactate value for the period of stay in the CCU was $1.9 \pm 1$.

The mean duration of the stay in the CCU was $10.9 \pm 11.8$ days (the shortest was $1 \mathrm{~d}$ and the longest was $88 \mathrm{~d}$ ). The mean duration of total hospital stay was $14 \pm 13$ days (the shortest was $2 \mathrm{~d}$ and the longest was $88 \mathrm{~d}$ ).

Patients who were followed up in the CCU for $<7$ days and $>7$ days were compared with the those who survived and those who died in 28 days and 3 months in terms of lactate and RDW values and APACHE II and SOFA scores. Age, gender, and APACHE II and SOFA scores at first admission and at $48 \mathrm{~h}$, mean RDW values at first admission and at $24 \mathrm{~h}$, mean value at 24 and $48 \mathrm{~h}$, and mean lactate value during the whole hospital stay were compared between the groups. Also, the total duration of stay and the duration of stay in the CCU were compared between groups. Patients diagnosed with respiratory failure were excluded while assessing RDW.

The comparison of statistics of the patients followed up in the CCU for $<7$ days and $>7$ days is shown in Table 2 . The total duration of stay of the patients followed up in the CCU for $<7$ days was $7.5 \pm 6.2$ days. The total duration of stay of the patients followed up in the CCU for $\geq 7$ days was $20.1 \pm 14.4$ days $(p<0.001)$.

The comparison of statistics for the patients who survived and those who died in 28 days is shown in Table 3. A statistically signif- 
Table 2. Comparison of age, gender, APACHE II score, SOFA score, duration of stay, mean lactate, and RDW values of the patients for the duration of stay in the CCU shorter than 7 days and longer than 7 days

\begin{tabular}{|c|c|c|c|c|c|}
\hline Duration of stay & <7 Days & & $\geq 7$ Days & & $\mathbf{P}$ \\
\hline \multirow[t]{2}{*}{$\begin{array}{l}\text { Age, year } \\
\text { (mean } \pm S D)\end{array}$} & $67 \pm 15$ & & $67.6 \pm 16$ & & 0.834 \\
\hline & $\mathrm{n}$ & $\%$ & $\mathrm{n}$ & $\%$ & \\
\hline \multicolumn{6}{|l|}{ Gender } \\
\hline Male & 35 & 50.7 & 43 & 55.1 & 0.593 \\
\hline Female & 34 & 49.3 & 35 & 44.9 & \\
\hline APACHE II & $15 \pm 6.3$ & & $17 \pm 6.9$ & & 0.080 \\
\hline $\begin{array}{l}\text { SOFA at first } \\
\text { admission }\end{array}$ & $5.3 \pm 2.7$ & & $5.8 \pm 2.9$ & & 0.301 \\
\hline SOFA at $48 \mathrm{~h}$ & $5.5 \pm 3.3$ & & $6.2 \pm 2.7$ & & 0.144 \\
\hline $\begin{array}{l}\text { RDW at first } \\
\text { admission }\end{array}$ & $13.8 \pm 2.4$ & & $13.9 \pm 2.6$ & & 0.724 \\
\hline $\mathrm{RDW}$ at $48 \mathrm{~h}$ & $13.9 \pm 2.7$ & & $13.9 \pm 2.6$ & & 0.989 \\
\hline $\begin{array}{l}\text { Mean RDW } \\
\text { (during stay) }\end{array}$ & $13.7 \pm 2.5$ & & $14 \pm 2.6$ & & 0.381 \\
\hline $\begin{array}{l}\text { Lactate at first } \\
\text { admission }\end{array}$ & $2.2 \pm 1.4$ & & $2.9 \pm 3.1$ & & 0.749 \\
\hline Lactate at $24 \mathrm{~h}$ & $2.2 \pm 2$ & & $1.7 \pm 1$ & & 0.418 \\
\hline $\begin{array}{l}\text { Mean lactate } \\
\text { value during } 24 \mathrm{~h}\end{array}$ & $2.3 \pm 1.8$ & & $2.2 \pm 1.7$ & & 0.561 \\
\hline Lactate at $48 \mathrm{~h}$ & $1.8 \pm 1.6$ & & $1.7 \pm 1$ & & 0.256 \\
\hline $\begin{array}{l}\text { Mean lactate } \\
\text { (during stay) }\end{array}$ & $1.9 \pm 1.3$ & & $1.8 \pm 0.9$ & & 0.796 \\
\hline $\begin{array}{l}\text { Duration of } \\
\text { stay in the CCU }\end{array}$ & $3.8 \pm 1.4$ & & $17.2 \pm 13.5$ & & 0.000 \\
\hline $\begin{array}{l}\text { Total duration } \\
\text { of stay }\end{array}$ & $7.5 \pm 6.2$ & & $20.1 \pm 14.4$ & & 0.000 \\
\hline
\end{tabular}

APACHE II: acute physiology and chronic health evaluation II;

SOFA: sequential organ failure assessment; RDW: red cell distribution width; CCU: critical care unit

icant difference was observed between the patients who survived and died in 28 days in terms of APACHE II score $(p=0.001)$. A statistically significant difference was found between the SOFA scores at the first admission and at $48 \mathrm{~h}(\mathrm{p}<0.001)$. Moreover, a statistically significant difference in the lactate level at the first admission was observed ( $p=0.032$ ). A statistically significant difference was noted between lactate values at $24 \mathrm{~h}$, mean value at $24 \mathrm{~h}$, and mean value during the hospital stay $(p<0.001)$. Also, a statistically significant difference was observed in lactate values at $48 \mathrm{~h}(\mathrm{p}=0.001)$. Moreover, a statistically significant difference was found in the RDW values at first admission and at $48 \mathrm{~h}$ and the mean RDW value $(p=0.013, p=0.029$, and $p=0.021$, respectively).

The comparison of the statistics for the patients who survived and those who died in 3 months is shown in Table 4. No statistically significant difference was found between the patients who survived and those who died in 3 months in terms of age, gender, and total duration of the stay. The APACHE II score at first admission and the SOFA score at
Table 3. Comparison of age, gender, APACHE II score, SOFA score, duration of stay, mean lactate, and RDW values in terms of 28-day mortality

\begin{tabular}{|c|c|c|c|c|c|}
\hline Clinical result & Dead & & Alive & & $\mathbf{p}$ \\
\hline \multirow[t]{2}{*}{$\begin{array}{l}\text { Age, year } \\
(\text { mean } \pm S D)\end{array}$} & $70 \pm 13.2$ & & $65.8 \pm 16.6$ & & 0.114 \\
\hline & $n$ & $\%$ & $\mathrm{n}$ & $\%$ & \\
\hline \multicolumn{6}{|l|}{ Gender } \\
\hline Male & 31 & 59.6 & 47 & 49.5 & 0.239 \\
\hline Female & 21 & 40.4 & 48 & 50.5 & \\
\hline APACHE II & $18.6 \pm 6.7$ & & $14.7 \pm 6.2$ & & 0.001 \\
\hline $\begin{array}{l}\text { SOFA at first } \\
\text { admission }\end{array}$ & $6.8 \pm 3$ & & $4.9 \pm 2.5$ & & 0.000 \\
\hline SOFA at $48 \mathrm{~h}$ & $7.2 \pm 3.3$ & & $4.9 \pm 2.3$ & & 0.000 \\
\hline $\begin{array}{l}\text { RDW at first } \\
\text { admission }\end{array}$ & $14 . \pm 2.6$ & & $13.6 \pm 2.4$ & & 0.013 \\
\hline RDW at $48 \mathrm{~h}$ & $14.5 \pm 2.9$ & & $13.4 \pm 2.2$ & & 0.029 \\
\hline $\begin{array}{l}\text { Mean RDW } \\
\text { (during stay) }\end{array}$ & $14.5 \pm 2.6$ & & $13.4 \pm 2.3$ & & 0.021 \\
\hline $\begin{array}{l}\text { Lactate at first } \\
\text { admission }\end{array}$ & $3.2 \pm 3$ & & $2.2 \pm 2$ & & 0.032 \\
\hline Lactate at $24 \mathrm{~h}$ & $2.7 \pm 2.1$ & & $1.4 \pm 0.7$ & & 0.000 \\
\hline $\begin{array}{l}\text { Mean lactate } \\
\text { value during } 24 \mathrm{~h}\end{array}$ & $3 \pm 2.2$ & & $1.7 \pm 1$ & & 0.000 \\
\hline Lactate at $48 \mathrm{~h}$ & $2.1 \pm 1.7$ & & $1.5 \pm 0.9$ & & 0.001 \\
\hline $\begin{array}{l}\text { Mean lactate } \\
\text { (during stay) }\end{array}$ & $2.4 \pm 1.4$ & & $1.6 \pm 0.7$ & & 0.000 \\
\hline $\begin{array}{l}\text { Duration of stay } \\
\text { in the } C C U\end{array}$ & $9.2 \pm 6.2$ & & $11.9 \pm 14$ & & 0.704 \\
\hline $\begin{array}{l}\text { Total duration } \\
\text { of stay }\end{array}$ & $10.2 \pm 6.6$ & & $16.4 \pm 15$ & & 0.045 \\
\hline
\end{tabular}

$48 \mathrm{~h}$ were higher in the patients who died than in those who survived $(\mathrm{p}<0.001)$. Lactate values at first admission and at $24 \mathrm{~h}$, mean value at $24 \mathrm{~h}$, and mean value during the hospital stay was different in the patients who died compared to those who survived $(p=0.012, p=0.002$, and $p<0.001$, respectively). RDW values at first admission, at $48 \mathrm{~h}$, and during the stay in the CCU were higher in the patients who died than in those who survived ( $p=0.016, p=0.015$, and $p=0.024$, respectively).

The duration of stay in the CCU was higher in the patients who died than in those who survived. A statistically significant increase in mortality was detected with the increase in the duration of stay in the CCU $(p=0.042)$.

Finally, it was assessed whether a correlation existed in terms of age, gender, APACHE II scores, SOFA scores (at first admission and at 48 $\mathrm{h}$ ), RDW values (at first admission and at $48 \mathrm{~h}$ and mean value during the hospital stay), lactate values (at first admission and at $24 \mathrm{~h}$, mean value at $24 \mathrm{~h}$ and $48 \mathrm{~h}$, and mean value during the hospital stay), duration of stay in the $\mathrm{CCU}$, and total hospitalization duration. A correlation was found between the SOFA score at first admission and RDW value at 
Table 4. Comparison of age, gender, APACHE II score, SOFA score, duration of stay, mean lactate, and meand RDW values of the patients that died and survived in 3 months

\begin{tabular}{|l|c|c|c|c|c|}
\hline Clinical result & Dead & & Alive & & p \\
\hline $\begin{array}{l}\text { Age, year } \\
\text { (mean } \pm \text { SD) }\end{array}$ & $68.4 \pm 14.8$ & & $66.7 \pm 16.2$ & & 0.509 \\
\hline & $\mathrm{n}$ & $\%$ & $\mathrm{n}$ & $\%$ & \\
\hline Gender & 34 & 57.6 & 44 & 50 & 0.364 \\
\hline Male & 25 & 42.4 & 44 & 50 & \\
\hline Female & $18.5 \pm 6.8$ & & $14.5 \pm 6$ & & 0.000 \\
\hline APACHE II & $6.7 \pm 2.9$ & & $4.8 \pm 2.5$ & & 0.000 \\
\hline $\begin{array}{l}\text { SOFA at first } \\
\text { admission }\end{array}$ & $7.5 \pm 3$ & & $4.8 \pm 2.4$ & & 0.000 \\
\hline SOFA at 48 h & $14.4 \pm 2.6$ & & $13.2 \pm 2$ & & 0.016 \\
\hline $\begin{array}{l}\text { RDW at first } \\
\text { admission }\end{array}$ & $14.4 \pm 2.8$ & & $13.3 \pm 2.2$ & & 0.015 \\
\hline RDW at 48 $\mathrm{h}$ & $14.4 \pm 2.6$ & & $13.4 \pm 2.3$ & & 0.024 \\
\hline $\begin{array}{l}\text { Mean RDW } \\
\text { (during stay) }\end{array}$ & $3.1 \pm 2.9$ & & $2.2 \pm 2.1$ & & 0.012 \\
\hline $\begin{array}{l}\text { Lactate at first } \\
\text { admission }\end{array}$ & $2.4 \pm 1.9$ & & $1.5 \pm 0.9$ & & 0.002 \\
\hline $\begin{array}{l}\text { Lactate at 24 } \mathrm{h} \\
\text { Mean lactate } \\
\text { value during } 24 \mathrm{~h}\end{array}$ & $2.8 \pm 2.1$ & & $1.7 \pm 1$ & & 0.000 \\
\hline Lactate at 48.hour & $2 \pm 1.6$ & & $1.5 \pm 0.9$ & & 0.011 \\
\hline $\begin{array}{l}\text { Mean lactate } \\
\text { (during stay) }\end{array}$ & $2.3 \pm 1.3$ & & $1.6 \pm 0.7$ & & 0.000 \\
\hline $\begin{array}{l}\text { Duration of stay } \\
\text { in the CCU }\end{array}$ & $13.4 \pm 15$ & & $9.2 \pm 8.8$ & & 0.042 \\
\hline $\begin{array}{l}\text { Total duration } \\
\text { of stay }\end{array}$ & & & & & \\
\hline APACHE & & & & & \\
\hline
\end{tabular}

APACHE II: acute physiology and chronic health evaluation II;

SOFA: sequential organ failure assessment; RDW: red cell distribution width; CCU: critical care unit

first admission, mean RDW value during the hospital stay, and lactate value at first admission ( $p=0.025, p=0.043$, and $p=0.011$, respectively). A correlation was observed between the SOFA score at $48 \mathrm{~h}$ and RDW value at $48 \mathrm{~h}$ and mean RDW value during the hospital stay $(p=0.04$ and $p<0.001$, respectively). Also, a correlation was observed between the lactate value at $48 \mathrm{~h}$ and RDW value at $48 \mathrm{~h}$ and mean RDW value during the hospital stay ( $p=0.003$ and $p=0.005$, respectively). Moreover, a correlation was noted between the APACHE II score and SOFA score at first admission $(r=0.682)$ and the SOFA score at $48 \mathrm{~h}(\mathrm{r}=631$; $p<0.001$ and $p<0.001$, respectively) (Figure 2 ).

\section{Discussion}

Critical patients are those with unstable life functions, who are receiving supportive treatment, with poor general conditions, and generally treated in ICUs (7).
The lifespan has been prolonged due to the improvement in life conditions and higher access rates of patients to health services with development in medical sciences.

The available literature shows that $46 \%$ of the patients hospitalized in the ICUs are older patients (8). This has led to a significant increase in mortality rates of the older patients hospitalized in the ICUs (9-11). Most of the patients in the present study were older patients. However, a 7-day stay in the CCU, 28-day and 3-month mortality, and age were not found to be significantly correlated. This might be due to the differences between diagnoses of age groups, scores, and the lack of classification according to the age groups. It is necessary to assess the influence of age on mortality rates of different patient groups in terms of diagnosis, gender, APACHE II and SOFA scores, and Glasgow Coma Score.

Mahmood et al. (12) explored the relation between age and clinical course and found no significant difference between female and male patients who were aged 50 years and older, but the mortality at the age of 50 years was lower in female patients than in male patients. Jacobson et al. (13) conducted a prospective observational cohort with the patients internalized in the ICU for a 3-year period; with sepsis in the first $24 \mathrm{~h}$, no correlation was found between mortality, hospitalization duration, and gender. The present study found no statistically significant difference between the genders in terms of the 28-day and 3-month mortalities ( $p>0.05$ ).

Another study by Wang et al. (14) performed in collaboration with medical and surgical ICUs in Canada assessed 1960 patients, and the most frequent reason for hospitalization was found to be multiple trauma and septic shock, followed by respiratory problems (14). Two and three patients had sepsis and respiratory problems, respectively, in the present study, whereas one patient had multiple organ failure due to several reasons. This might be because the current CCU was a general ICU.

Clinical findings in the ICU and laboratory results are used to estimate the prognosis and death risk of the patients in the ICUs. Lactate is one of the most frequent and easily assessed parameters used in shock and other critical diseases (15). Higher lactate values must be considered as a useful indicator in identifying the severity of diseases and mortality rates (16-19). On the contrary, some studies showed the first lactate values as a weak indicator of mortality (20). The present study found a statistically significant difference between lactate values at first admission and at $24 \mathrm{~h}$, mean values at $24 \mathrm{~h}, 48 \mathrm{~h}$, and during the stay, and 28-day and 3-month mortalities. However, a higher $P$ value was reported for the lactate values at the first admission. Lactate values other than the value at the first admission were more significant.

However, the number of studies on RDW values used in daily practice but not receiving sufficient attention has increased recently. RDW was found to be related to mortality and hospitalization duration. Therefore, RDW is a parameter to be focused on. Physiologic mechanisms (oxidative stress, inflammation, and weak pulmonary function) with higher RDW rates and higher death rates in terms of cardiovascular mortality have been demonstrated but are not completely known $(21,22)$. Wang et al. (14) found a correlation between higher RDW rates and the APACHE II score. They also found the RDW value to correlate with mortality and duration of stay. Hunziker et al. (23) showed the prognostic value of RDW for ICU mortality, in-hospital mortality, and Simplified Acute Physiology Score (SAPS). The present study found a correlation between RDW value and 28-day and 3-month mortality. Moreover, a correlation was observed between RDW values, SOFA scores at the first admission and at $48 \mathrm{~h}$, and lactate values at $48 \mathrm{~h}$. 

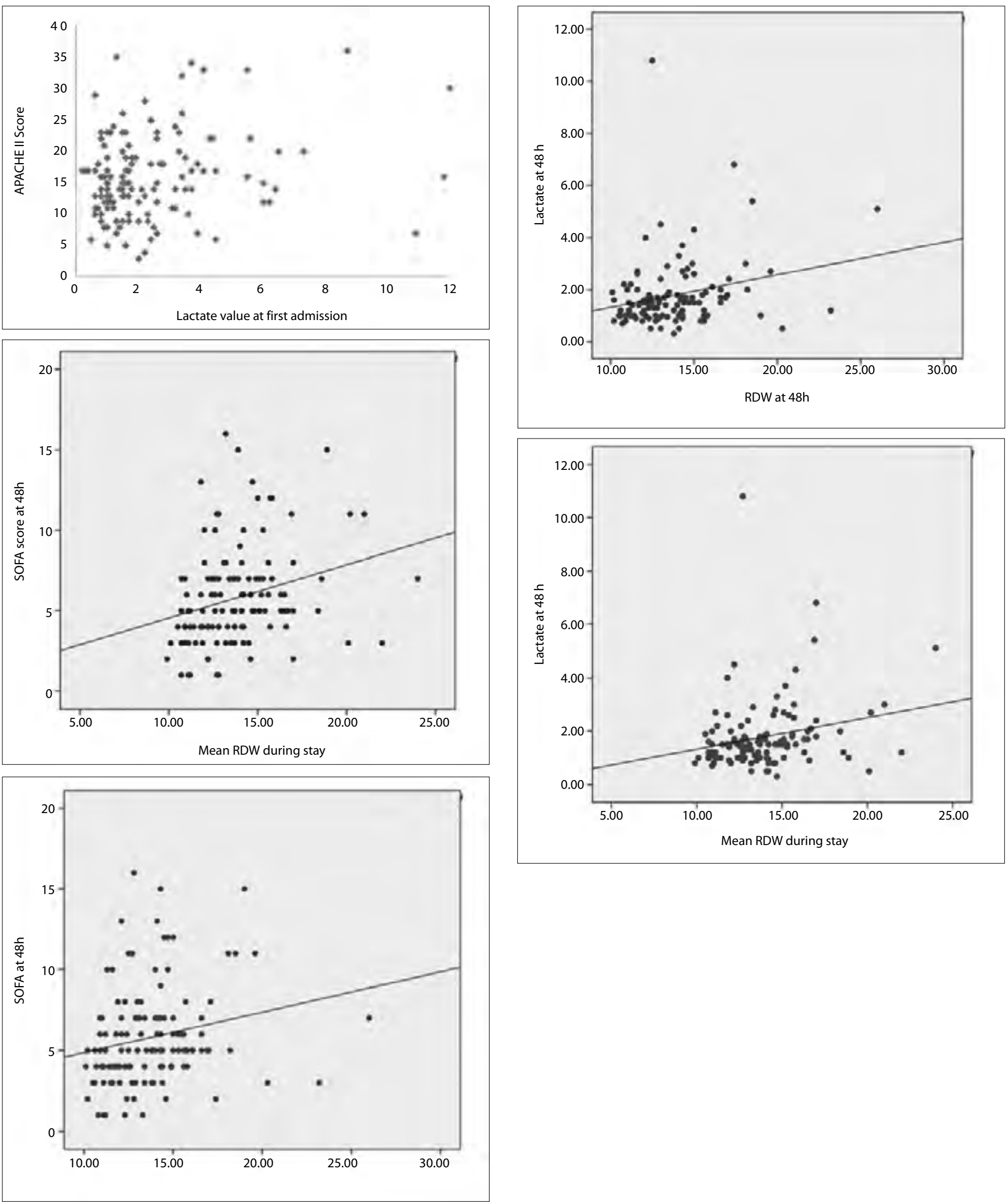

Figure 2. a-e. (a) Correlation between the lactate value at first admission and APACHE II score, (b) Correlation between the mean RDW value during stay and SOFA score at $48 \mathrm{~h}$, (c) Correlation between the RDW value and SOFA score at $48 \mathrm{~h}$, (d) Correlation between the RDW value and lactate value at $48 \mathrm{~h}$, (e) Correlation between the mean RDW value during stay and lactate value at $48 \mathrm{~h}$ APACHE II: acute physiology and chronic health evaluation II; SOFA: sequential organ failure assessment; RDW: red cell distribution width 
The present study found a correlation between one of the most commonly used parameters APACHE II and SOFA scores with 28day and 3-month mortalities. Hantke et al. (24) assessed SOFA and APACHE II scores in 874 surgical intensive care patients and found the values below the line identified for mortality ( 0.73 for APACHE II and 0.71 for SOFA). Timsit et al. (25) calculated SOFA scores for each day in a 1-week period for 1685 intensive care patients. For the first week in the ICU, the SOFA score was used to estimate mortality, and was suggested for use to estimate contributions of background diseases to death risk. The estimation of mortality for the patients in the CCU by using APACHE II and SOFA scores in the present study was compatible with the literature. APACHE II and SOFA scores were found to correlate with mortality. Higher statistically significant APACHE II and SOFA scores were observed in the patients who died while assessing the 28-day and 3-month mortalities.

\section{Conclusion}

Therefore, APACHE II and SOFA scores continue to be an important guide for estimating mortality. Lactate and RDW values, which are compatible with scoring systems, are considered prognostic indicators. Also, more comprehensive studies will help in assessing the parameters that can be used for the prognosis of critical patients.

Ethics Committee Approval: Ethics committee approval was received for this study from the ethics committee of Necmettin Erbakan University School of Medicine (18.01.2013, Decision No: 2013-332).

Informed Consent: Written informed consent was obtained from patients who participated in this study.

Peer-review: Externally peer-reviewed.

Conflict of Interest: No conflict of interest was declared by the authors.

Financial Disclosure: The authors declared that this study has received no financial support.

\section{References}

1. Bektemur G, Osmanbeyoglu N, Cander B. Emergency Department Care Survey. Eurasian J Emerg Med 2015; 14: 1-33. [CrossRef]

2. García Sanz C, Rupérez Lucas M, López-Herce Cid J, Vigil Escribano D, Garrido Cantarero G. Prognostic value of the pediatric index of mortality (PIM) score and lactate values in critically-ill children. An Esp Pediatr 2002; 57: 394-400. [CrossRef]

3. Gotay-Cruz F, Avilés-Rivera DH, Fernández-Sein A. Lactic acid levels as prognostic measure in acutely ill patients. PR Health Sci J 1991; 10: 9-13.

4. Kliegel A, Losert H, Sterz F, Holzer M, Zeiner A, Havel C, et al. Serial lactate for prediction of outcome after cardiac arrest. Medicine (Baltimore) 2004; 83: 274-9. [CrossRef]

5. Karnad A, Poskitt TR. The automated complete blood cell count. Use of the red blood cell volume distribution width and mean platelet volume in evaluating anemia and thrombocytopenia. Arch Intern Med 1985; 145: 1270-2. [CrossRef]
6. Hampole CV, Mehrotra AK, Thenappan T, Gomberg-Maitland M, Shah SJ. Usefulness of red cell distribution width as a prognostic marker in pulmonary hypertension. Am J Cardiol 2009; 104: 868-72. [CrossRef]

7. Cander B, Dundar ZD, Gul M, Girisgin S. Prognostic value of serum zinc levels in critically ill patients. J Crit Care 2011; 26: 42-6. [CrossRef]

8. Aulbert $E$, Steffens $O$. Serum ferritin-a tumor marker in malignant lymphomas. Onkologie 1990; 13: 102-8.

9. Trivedi TH, Shejale SB, Yeolekar ME. Nosocomial pneumonia in medical intensive care unit. J Assoc Physicians India 2000; 48: 1070-3.

10. Scott BH, Seifert FC, Grimson R, Glass PS. Octogenarians undergoing coronery artery bypass graft surgery: resource utilization, postoperative mortality and morbidity. J Cardiothorac Vasc Anesth 2005; 19: 583-8. [CrossRef]

11. Seferian EG, Afessa B. Adult intensive care unit use at the end of life: a population-based study. Mayo Clin Proc 2006; 81: 896-901. [CrossRef]

12. Mahmood K, Eldeirawi K, Wahidi MM. Association of gender with outcomes in critically ill patients. Crit Care 2012; 16: R92. [CrossRef]

13. Jacobson S, Liedgren E, Johansson G, Ferm M, Winsö O. Sequential Organ Failure Assessment (SOFA) scores differ between genders in a sepsis cohort: Cause or effect? Ups J Med Sci 2012; 117: 415-25. [CrossRef]

14. Wang F, Pan W, Pan S, Ge J, Wang S, Chen M. Red cell distribution width as a novel predictor of mortality in ICU patients. Ann Med 2011; 43: 40-6. [CrossRef]

15. Deshpande SA, Platt MP. Association between blood lactate and acid-base status and mortality in ventilated babies. Arch Dis Child Feta Neonatal Ed 1997; 76: F15-20.

16. Cheung PY, Robertson CM, Finer NN. Plasma lactate as a predictor of early childhood neurodevelopmental outcome of neonates with severe hypoxemia requiring extracorporeal membrane oxygenation. Arch Dis Child 1996; 74: F47-50. [CrossRef]

17. Smith I, Kumar P, Molloy S, Rhodes A, Newman PJ, Grounds RM, et al. Base excess and lactate as prognostic indicators for patients admitted to intensive care. Intensive Care Med 2001; 27: 74-83. [CrossRef]

18. Nguyen HB, Rivers EP, Knoblich BP, Jacobsen G, Muzzin A, Ressler JA, et al. Early lactate clearance is associated with improved outcome in severe sepsis and septic shock. Crit Care Med 2004; 32: 1637-42. [CrossRef]

19. Schulman AM, Claridge JA, Carr G, Diesen DL, Young JS. Predictors of patients who will develop prolonged occult hypoperfusion following blunt trauma. J Trauma 2004; 57: 795-800. [CrossRef]

20. Hatherill M, Sajjanhar T, Tibby SM, Champion MP, Anderson D, Marsh MJ, et al. Serum lactate as a predictor of mortality after paediatric cardiac surgery. Arch Dis Child 1997; 77: 235-8. [CrossRef]

21. Horne BD, May HT, Muhlestein JB, Ronnow BS, Lappé DL, Renlund DG, et al. Exceptional mortality prediction by risk scores from common laboratory tests. Am J Med 2009; 122: 550-8. [CrossRef]

22. Garcez, ME, Peres, W, Salvador, M. Oxidative stress and hematologic and biochemical parameters in individuals with Down syndrome. Mayo Clin Proc 2005; 80: 1607-11. [CrossRef]

23. Hunziker1 S, Celi1 LA, Lee J, Howell MD. Red cell distribution width improve Critical Care 2012;16:R89 20

24. Hantke $M$, Holzer $K$, Thöne $S$, Schmandra T, Hanisch E. The SOFA score in evaluating septic illnesses. Correlations with the MOD and APACHE II score. Chirurg 2000; 71: 1270-6. [CrossRef]

25. Timsit JF, Fosse JP, Troché G, De Lassence A, Alberti C, Garrouste-Orgeas $M$, et al. Calibration and discrimination by daily Logistic Organ Dysfunction scoring comparatively with daily Sequential Organ Failure Assessment scoring for predicting hospital mortality in critically ill patients. Crit Care Med 2002; 30: 2003-13. [CrossRef] 